

論文受付

2015 年 12 月 18 日

論文受理

2016 年 6 月 19 日

Code No. 522

\section{FPD を用いた血管撮影システムにおける cone beam CT の 画像収集条件と回転中心からの位置 (XYZ 方向)が 基本的な画質特性に及ぼす影響}

\author{
津田規吏 三井宏太 織田信一郎
}

地方独立行政法人佐賀県医療センター好生館放射線部

\section{緒 言}

近年, flat panel detector(FPD)を用いた血管撮影シ ステムが普及し, FPD の広い検出野にX 線を平面で 照射し回転撮影を行う cone beam computed tomography $(\mathrm{CBCT})$ の撮影が多くの施設で行われている. コーンビームによって被写体の投影像を得るため, コーン角の影響を考慮した feldkamp 法 ${ }^{1)}$ による画像 再構成アルゴリズムが用いられ，CT 様の断層画像が 出力される。これまでに $\mathrm{CBCT}$ の臨床的な有用性に ついては報告されており, 頭部や腹部の血管内治療に おいて診断上有益な画像情報を提供している
に, 呼吸器や消化器領域における非血管系 interventional radiology (IVR)でもCBCTは利用されており， 多くの分野で三次元情報を得る画像支援ツールとして 普及している。

診断用の一般的な CT 装置では，X線管が被写体の 周りを 1 回転し, 360 度全方向から投影デー夕を取得, 再構成することで CT 画像を得る ${ }^{5)}$. その画質特性は, 投影デー夕収集時の投影デー夕数 (view 数) やスライ ス面 (X-Y 面)内の位置によって変化することが報告 されている ${ }^{6)}$ ．血管撮影システムに扔ける $\mathrm{CBCT}$ の画 像収集方法は CT 装置と異なり, 360 度回転撮影を行

\title{
Evaluation for Basic Image Qualities Dependence on the Position in XYZ Directions and Acquisition Parameters of the Cone Beam CT for Angiography System with Flat Panel Detector
}

\author{
Norisato Tsuda, ${ }^{*}$ Kota Mitsui, and Shinichiro Oda \\ Division of Radiology, Saga-ken, Medical Centre Koseikan \\ Received December 18, 2015; Revision accepted June 19, 2016 \\ Code No. 522
}

\begin{abstract}
Summary
The purpose of this study was to investigate the effect of the position in XYZ directions and acquisition parameters on the basic image qualities of for cone beam computed tomography (CBCT) in an angiography system with flat panel detector. The resolution property (modulation transfer function: MTF) and the noise property (Wiener spectrum: WS) of CBCT images in X-Y plane were measured with different acquisition parameters (scan matrix number and projection number) and the effect of the position in XYZ directions. The MTFs with $1024 \times 1024$ matrix were higher than those of $512 \times 512$ matrix and decreased in the peripheral areas due to the reduction of projection number. The highest and the lowest MTFs were measured at the X-ray tube side and on the detector side of the position in X-Y plane, respectively. The WS-doubled projection number showed about $50 \%$ lesser noise level. There were differences in the Wiener spectra (WS) at the position in XYZ directions. We conclude that the resolution and the noise property of CBCT image in X-Y plane showed dependences on the position in XYZ directions and acquisition parameters of the $\mathrm{CBCT}$.
\end{abstract}

Key words: cone beam computed tomography (CBCT), flat panel detector (FPD), modulation transfer function (MTF), Wiener spectrum (WS), angiography system

*Proceeding author 
Table 1 Acquisition parameters of cone beam computed tomography (CBCT) images using propeller-rotation employed in this study

\begin{tabular}{|c|c|c|c|c|}
\hline Allura Xper FD20 & $30 \mathrm{f} / \mathrm{s}-10 \mathrm{~s}$ & $30 \mathrm{f} / \mathrm{s}-20 \mathrm{~s}$ & $60 \mathrm{f} / \mathrm{s}-5 \mathrm{~s}$ & $60 \mathrm{f} / \mathrm{s}-10 \mathrm{~s}$ \\
\hline Frame rate $[$ frame $/ \mathrm{s}]$ & \multicolumn{2}{|c|}{30} & \multicolumn{2}{|c|}{60} \\
\hline Exposure time $[\mathrm{s}]$ & 10 & 20 & 5 & 10 \\
\hline Scan matrix number & \multicolumn{2}{|c|}{$1024 \times 1024$} & \multicolumn{2}{|c|}{$512 \times 512$} \\
\hline Sampling distance $[\mathrm{mm}]$ & \multicolumn{2}{|c|}{0.308} & \multicolumn{2}{|c|}{0.616} \\
\hline Number of projection image & 308 & 617 & 308 & 617 \\
\hline Focal spot size of X-ray tube $[\mathrm{mm}]$ & \multicolumn{4}{|c|}{0.7} \\
\hline Rotation angle [degree] & \multicolumn{4}{|c|}{240} \\
\hline Tube voltage $[\mathrm{kV}]$ & \multicolumn{4}{|c|}{120} \\
\hline Tube current $[\mathrm{mA}]$ & \multicolumn{2}{|c|}{250} & \multicolumn{2}{|c|}{170} \\
\hline
\end{tabular}

わない(partial-scan)，投影デー夕数が少ない，体軸方 向の X 線照射角 (コーン角)が広い, などの特徵をも つ。このように, CBCTではCT装置より制限された 条件のもとでデー夕収集を行うことから，投影デー夕 収集条件が画質に及ぼす影響が大きいことが予測され る. 脳血管内治療後の出血有無や腹部血管の走行を確 認する目的として, CBCT の撮影頻度は高く，特に頭 部領域においては脳実質と皮質が描出可能な画質が必 要とされるため, 投影デー夕収集条件による画質の変 化を把握しておくことは重要である。

これまでに，血管撮影システムに㧍ける CBCT の 投影デー夕収集条件と画質に関する報告は少なく，収 集マトリクス, 収集画像数, X 線管回転中心からの位 置, などの諸因子が $\mathrm{CBCT}$ 画像のスライス $(\mathrm{X}-\mathrm{Y})$ 面内 の解像特性とノイズ特性に及ぼす影響について明らか にすることが本研究の目的である。

\section{1. 方 法}

\section{1-1 使用機器と画像収集条件}

血管撮影装置は, 間接変換型 $\mathrm{FPD}$ (シンチレータ： ヨウ化セシウム，フォトダイオード：アモルファスシ リコン)が搭載された Allura Xper FD20（株式会社 フィリップスエレクトロニクスジャパン)を使用した。 評価に用いた CBCT 画像は, 撮影装置付属の workstationにより画像再構成を行った。画像の再構成ア ルゴリズムは feldkamp 法を用いた filtered back projection (FBP) 法再構成を使用し, 散乱線補正, ビーム ハードニング補正，トランケーション補正，リング アーチファクト補正の各補正処理が含まれている.

$\mathrm{CBCT}$ の撮影は, プロペラ回転方式による頭部撮影 プログラムの 4 種類を使用した (Table 1)。画像収集 レートが $60 \mathrm{frame} / \mathrm{s}$ では収集マトリクスが $512 \times 512$ となり，30 frame/s $(1024 \times 1024)$ と比べて小さい. 収 集 field of view(FOV)はすべての撮影条件において同
一サイズで, $512 \times 512$ 収集では $2 \times 2$ 画素を 1 画素とす る binning 処理によって投影データが収集され，撮影 線量は 1024×1024 収集と比べて 33\%少ない，焦点サ イズは, 各撮影条件で同一の $0.7 \mathrm{~mm}$ を使用した。

\section{1-2 コーン角中心における X-Y 面内の画質評価}

解像特性は, CT 装置の評価に使用されるワイヤー 法7を用いて modulation transfer function (MTF) を測 定し, 高コントラスト分解能を評価した。 ワイヤー像 は, $0.23 \mathrm{~mm}$ 径ステンレス製ワイヤーを水で満たした $40 \mathrm{~mm}$ 径シリンジの中に封入した自作ワイヤーファ ントムにより取得した。 ワイヤーファントムを，X-Y 面内の $+\mathrm{X},-\mathrm{X},+\mathrm{Y},-\mathrm{Y}$ の 4 方向に, それぞれ回転中 心から 30, 60, $90 \mathrm{~mm}$ の位置 (合計 12 力所)に配置し て撮影を行った (Fig. 1b)。一つの測定点におけるワ イヤー像の $\mathrm{X}$ 軸 (水平) $\cdot \mathrm{Y}$ 軸 (垂直) 方向の line spread function (LSF), それぞれ $\mathrm{LSF}_{\mathrm{X}}$ と $\mathrm{LSF}_{\mathrm{Y}}$ を取 得し, コーン角中心付近の連続した 5 スライスの LSF を平均した，これをフーリエ変換することで MTFを 算出し，12 の測定点に扔けるX 軸方向の $\mathrm{MTF}_{\mathrm{X}}$ と $\mathrm{Y}$ 軸方向の $\mathrm{MTF}_{\mathrm{Y}}$ を求めた.

ノイズ特性は, 二次元フーリエ変換法により Wiener spectrum (WS) を測定した ${ }^{8)}$. 均一性測定水 ファントム $(180 \mathrm{~mm} \Phi \times 300 \mathrm{~mm})$ を回転中心に配置 し，コーン角中心付近の連続したスライス 40 枚の WS を測定した。画像の中心部分の 256×256 画素に関 心領域 (region of interest: ROI) を設定し, X 軸・ Y 軸 方向の $\mathrm{WS}_{\mathrm{X}}$ ・WS をそれぞれ求めた。 また, スライ 又面内の 4 方向 $(+\mathrm{X},-\mathrm{X},+\mathrm{Y},-\mathrm{Y}$ 軸方向 $)$, 画像中心 から $60 \mathrm{~mm}$ の位置に ROI を設置し, 画像辺縁部 4 カ 所の WS を測定した (Fig. 1c). 更に, X-Y 面内の線量 分布とノイズ分布の関係を調べるため, 半導体検出器 (Piranha, アクロバイオ株式会社) と円柱アクリル ファントム $(160 \mathrm{~mm} \Phi \times 150 \mathrm{~mm})$ を用いて X-Y 面内の 

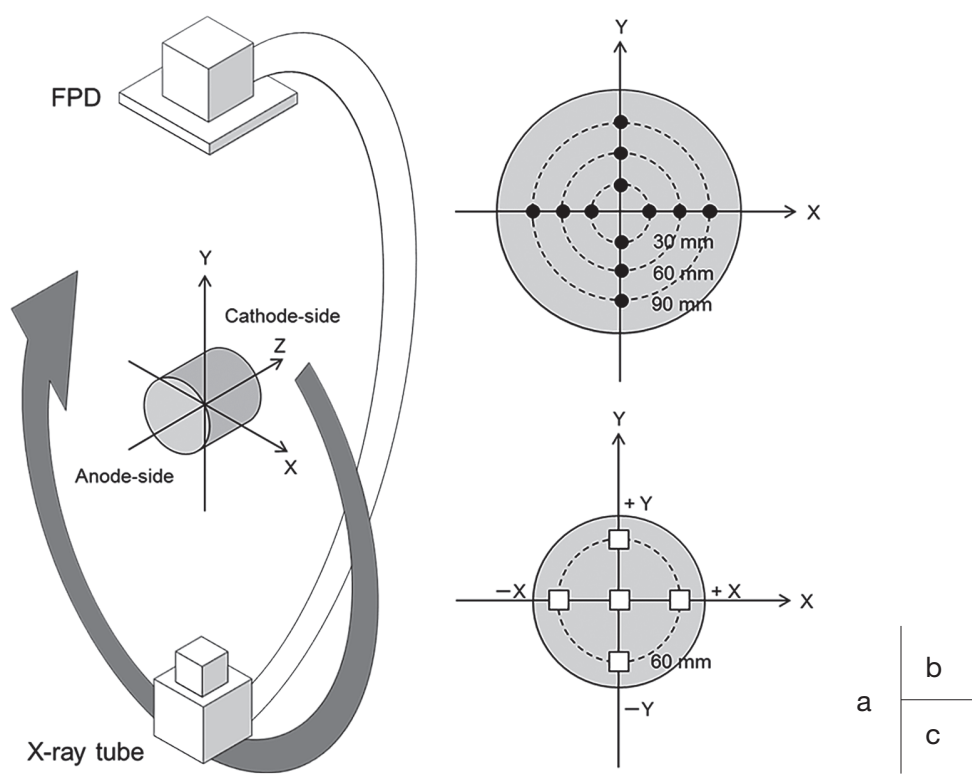

Fig. 1 Illustration of the imaging geometry for cone beam computed tomography (CBCT) using propeller-rotation on angiography system with flat panel detector (a) and measurement locations of MTF (b) and areas of WS (c) in the $\mathrm{X}-\mathrm{Y}$ plane used in this study.

Table 2 Acquisition parameters of cone beam computed tomography (CBCT) images used in validation study

\begin{tabular}{lcc}
\hline \hline & Allura Xper FD20 & Artis zee TA \\
\cline { 2 - 3 } & Roll-rotation & Propeller-rotation \\
\hline Frame rate [frame/s] & 30 & 25 \\
Exposure time [s] & 10 & 20 \\
Scan matrix number & $1024 \times 1024$ & $1024 \times 1024$ \\
Sampling distance [mm] & 0.308 & 0.308 \\
Number of projection image & 308 & 496 \\
Focal spot size of X-ray tube [mm] & 0.7 & 0.6 \\
Rotation angle [degree] & 240 & 200 \\
Tube voltage [kV] & 119 & 109 \\
Tube current [mA] & 188 & 212 \\
\hline
\end{tabular}

4 方向 $(+\mathrm{X},-\mathrm{X},+\mathrm{Y},-\mathrm{Y}$ 方向), 画像中心から $60 \mathrm{~mm}$ の位置と画像中心部に打ける吸収線量を測定した。 4 種類の撮影条件 (Table 1) での吸収線量值を平均し, 画 像中心部の值で各測定位置の值を正規化した.

MTF とWS の測定は，エリアシングエラーを考慮 し，再構成後の画素サイズが $0.08 \mathrm{~mm}(\mathrm{MTF})$ と 0.16 $\mathrm{mm}$ (WS) となる拡大再構成した画像を使用した7.8). スライス厚とスライス間隔は，それぞれ画素サイズと 同じく $0.08 \mathrm{~mm}(\mathrm{MTF})$ と $0.16 \mathrm{~mm}(\mathrm{WS})$ である.

\section{1-3Ｚ 軸方向 (コーン角)の画質への影響}

コーン角が大きいスライス位置での画質特性を調べ るために、コーン角中心から体軸 ( $Z$ 軸) 方向の頭部
$(+Z)$ と足部 $(-Z)$ での解像特性とノイズ特性を調べた。 解像特性は, コーン角 ( $Z$ 軸) 中心の評価に用いた領域 のうち回転中心に近い $(X=+30 \mathrm{~mm}, Y=0 \mathrm{~mm}, Z=0$ $\mathrm{mm})$ の点を軸に, $\pm Z$ 方向にワイヤーファントムを 30，60，90 mm 移動させて MTF を測定した，ノイズ 特性は，散乱線の影響を同等にするために水ファント ム中心を $\pm Z$ 方向に $60 \mathrm{~mm}$ 移動させ，水ファントム中 心付近のスライスを選択し，画像中心部の WS を測定 した。また，X 線管の陰極一陽極方向がノイズ特性に 及ぼす影響を評価する目的で，Z 軸方向が陰極一陽極 方向に該当しないロール回転方式 (Table 2)により得 られた $\mathrm{CBCT}$ 画像のノイズ特性について, 回転中心 と $\pm Z$ 方向 $60 \mathrm{~mm}$ の位置に水ファントムを移動させ 


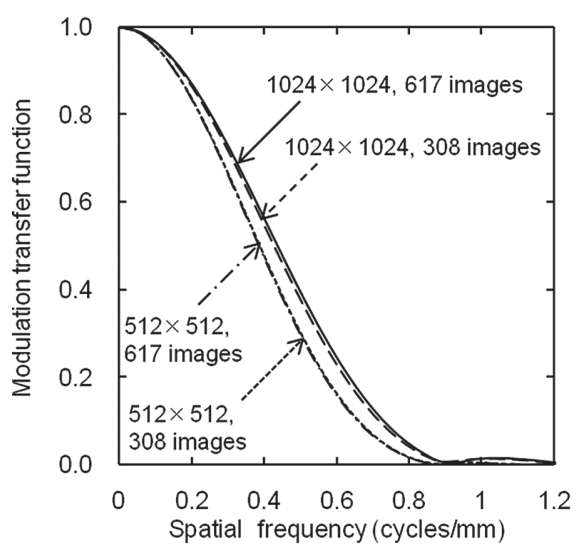

$(+30,0,0)$

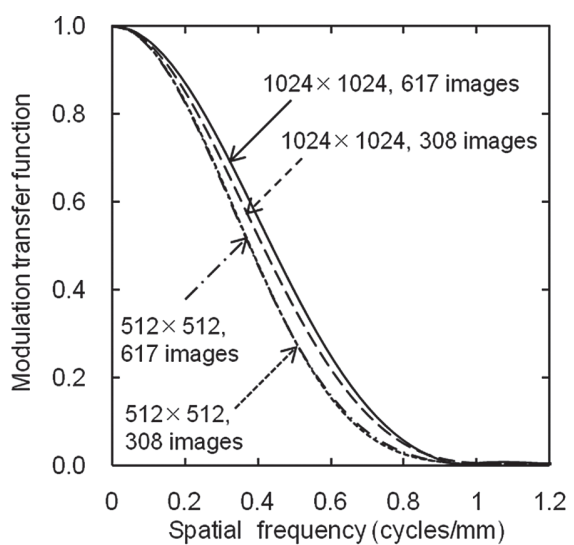

$(+90,0,0)$

Fig. 2 Comparisons of $\mathrm{MTF}_{\mathrm{Y}} \mathrm{S}$ measured with different acquisition parameters for scan matrix number of $1024 \times 1024$ and $512 \times 512$ and projection number of 308 and 617 images obtained at the position of $(+30,0,0)$ (a) and $(+90,0,0)(b)$ in the X-Y plane.
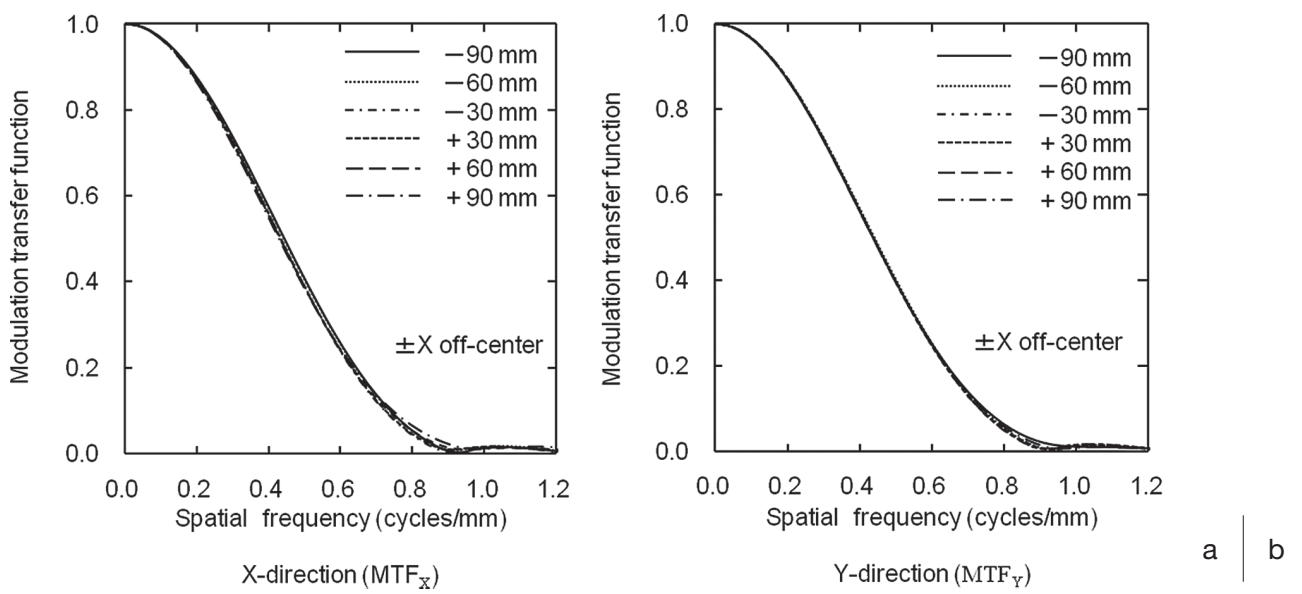

Fig. 3 Comparisons of $\mathrm{MTF}_{X S}$ (a) and $\mathrm{MTF}_{Y S}$ (b) measured at the position of various distance from the isocenter on the $\mathrm{X}$-axis acquired with $1024 \times 1024$ and 617 images.

て画像中心部の WS を測定した. MTF と WS はコー ン角中心の X-Y 面内の評価と同様の方法で測定を 行った。以下，MTF の測定位置とWS の測定領域の 中心位置を座標点 $( \pm X, \pm Y, \pm Z)$ で表す。

\section{2. 結 果}

2-1 画像収集条件と測定位置による X-Y 面内 $( \pm X$, $\pm Y, 0)$ の MTF の比較

4 種類の撮影条件で測定したMTFについて, $\mathrm{MTF}_{\mathrm{x}}$ と比べ測定位置による影響が小さかった $\mathrm{MTF}_{\mathrm{Y}}$ による比較を Fig. 2 に示す。収集マトリクス が512×512 の場合に低い MTF を示し，回転中心に近 い(+30, 0, 0) の位置では回転速度抢よび収集画像数の 違いで顕著な差はみられなかった(Fig. 2a)。回転中 心から離れた $(+90,0,0)$ の位置では, 収集マトリクス が 1024×1024の場合に収集画像数の減少により MTF
の低下がみられた (Fig. 2b)。これらは, ほかの 10 カ 所の測定点においても同様の傾向を示した，X-Y面 内の測定位置による MTF の比較を，Fig. $3( \pm \mathrm{X}$ 方向 $)$ と Fig. 4 ( \pm Y 方向 $)$ に示す. Table 3 には, 空間周波数 が 0.3 と 0.6 cycles $/ \mathrm{mm}$ に扔ける回転中心から 4 方向 $( \pm \mathrm{X}, \pm \mathrm{Y}$ 方向 $) \cdot 90 \mathrm{~mm}$ の位置での MTF の值を示 す. $\pm X$ 方向では, 回転中心からの方向・距離による 差がみられず, $\mathrm{MTF}_{\mathrm{X}}$ と MTF $\mathrm{MT}_{\mathrm{Y}}$ でぼ同じ值を示し た. $\pm \mathrm{Y}$ 方向では, $\mathrm{MTF}_{\mathrm{X}} \cdot \mathrm{MTF}_{\mathrm{Y}}$ ともに-Y 方向の $(0,-90,0)$ の位置で最も值が高く, $+Y$ 方向へ向かうに つれて低下し, $(0,+90,0)$ の位置で最も低くなった. 特に $\mathrm{MTF}_{\mathrm{X}}$ でその差が大きくみられた。

2-2 画像収集条件と測定位置による X-Y 面内 $( \pm X$, $\pm Y, 0) の$ WS $の$ 比較

画像中心領域で測定した $\mathrm{WS}_{X}$ と WS $\mathrm{W}_{\mathrm{Y}}$ の比較を Fig. 

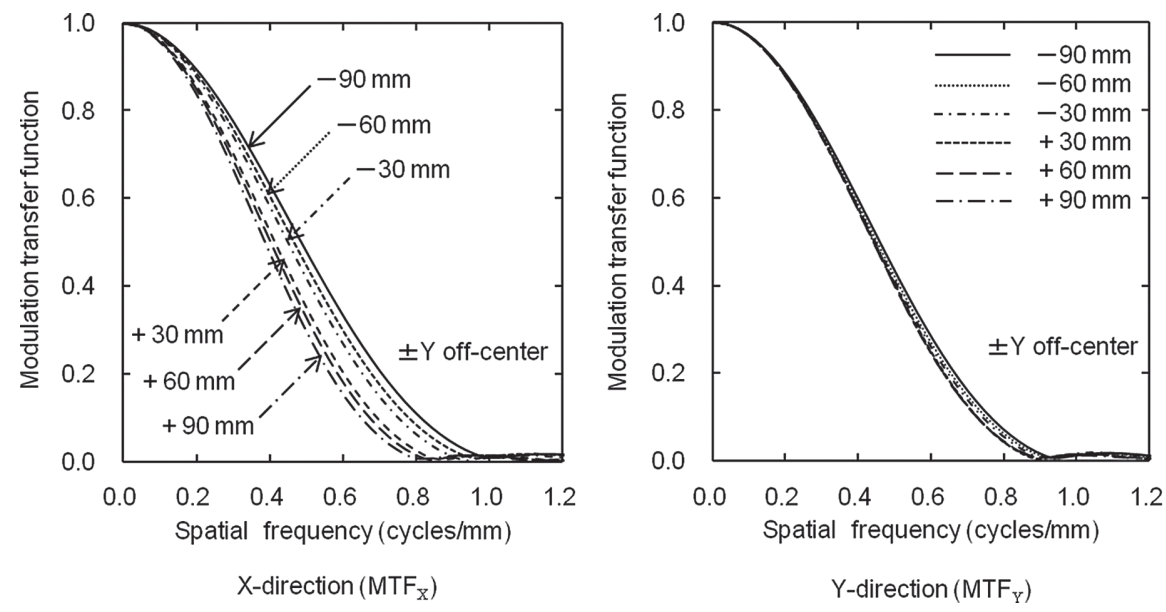

$a \mid b$

Fig. 4 Comparisons of $\mathrm{MTF}_{\mathrm{XS}}$ (a) and $\mathrm{MTF}_{\mathrm{Y} S}$ (b) measured at the position of various distance from the isocenter on the $\mathrm{Y}$-axis acquired with $1024 \times 1024$ and 617 images.

Table $3 \mathrm{MTF}_{\mathrm{X}}$ and $\mathrm{MTF}_{\mathrm{Y}}$ values of 0.3 and 0.6 cycles $/ \mathrm{mm}$ measured at the $90 \mathrm{~mm}$ distance positions from the isocenter on the $\mathrm{X}$ - and $\mathrm{Y}$-axis acquired with $1024 \times$ 1024 and 617 images

\begin{tabular}{cccc}
\hline \hline & $( \pm X, \pm Y, \pm Z)$ & $0.3[$ cycles $/ \mathrm{mm}]$ & $0.6[$ cycles $/ \mathrm{mm}]$ \\
\hline & $(+90,0,0)$ & 0.75 & 0.23 \\
MTF $_{X}$ & $(-90,0,0)$ & 0.77 & 0.25 \\
& $(0,+90,0)$ & 0.70 & 0.14 \\
& $(0,-90,0)$ & 0.80 & 0.32 \\
\hline \multirow{4}{*}{ MTFY $_{Y}$} & $(+90,0,0)$ & 0.76 & 0.24 \\
& $(-90,0,0)$ & 0.76 & 0.24 \\
& $(0,+90,0)$ & 0.77 & 0.23 \\
\hline
\end{tabular}

5 に示す。ゼロ周波数付近を除く空間周波数で WS に比べて $\mathrm{WS}_{\mathrm{X}}$ の值がわずかに高くなった. Fig. 6 に は，4種類の撮影条件で測定した画像中心部の WS に ついて，比較のために $\mathrm{WS}_{\mathrm{X}}$ と $\mathrm{WS}_{\mathrm{Y}}$ を平均したものを 示す。測定したWSにはエリアシング成分が含まれ ている ${ }^{8)}$ こから, 各撮影条件のナイキスト周波数 [0.81 (512×512), 1.62 (1024×1024) cycles/mm]以下に おける值を示す ${ }^{9)}$. 収集画像数を 2 倍にすると WS 值 が約 50\%低下し，ノイズ特性が改善している。収集画 像数が同じ場合は，回転速度および収集マトリクスの 違いで WS に顕著な差はみられなかった。これらは, 画像中心部以外の 4 力所の ROI およびほかの撮影条 件においても同様の結果を得た。 X-Y 面内辺縁部の

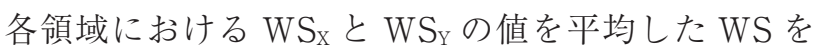
Fig. 7 に示す. 空間周波数が約 0.4 から 1.0 cycles/ $\mathrm{mm}$ 付近までの中周波数域では, 画像中心および士X 領域 $( \pm 60,0,0)$ と比べて $-Y$ 領域 $(0,-60,0)$ における WS 值が高く, +Y 領域 $(0,+60,0)$ で低い值を示した。 約 0.4 cycles $/ \mathrm{mm}$ の付近までの低周波数域と 1.0 cycles/mm 以降の高周波数域では, $\pm \mathrm{X}$ 領域は, $\pm \mathrm{Y}$ 領 域および画像中心領域より低い值を示した。

\section{2-3 X-Y 面内の線量分布}

画像中心から $60 \mathrm{~mm}$ の位置にあるX-Y 面内の各測 定点 $(+\mathrm{X},-\mathrm{X},+\mathrm{Y},-\mathrm{Y}$ 方向)における吸収線量を, 画像 中心部の值で正規化したものを Fig. 8 に示す。回転軌 道上の $\mathrm{X}$ 線管側である-Y 領域で最も線量が多く，反 対の検出器側である+Y 領域では最も少なかった。

\section{2-4Ｚ軸方向におけるコーン角の画質への影響}

$Z$ 軸方向に測定位置を変えたときの $\mathrm{MTF}_{\mathrm{Y}}$ とWS をFig. 9 に示す。 $\mathrm{MTF}_{\mathrm{X}}$ と $\mathrm{MTF}_{\mathrm{Y}}$ は同等の值を示し, コーン角中心 $(+30,0,0)$ からの Z 軸方向の位置による 差はみられなかった。 WS はコーン角中心と比べて陽 極方向 $(0,0,-60)$ で高く, 㓌極方向 $(0,0,+60)$ において 低い值を示した。これらは，収集画像数および収集マ トリクスを変更しても同様の結果を得た。また，ロー ル方向の回転撮影における，回転中心と $Z$ 軸方向 \pm 60 


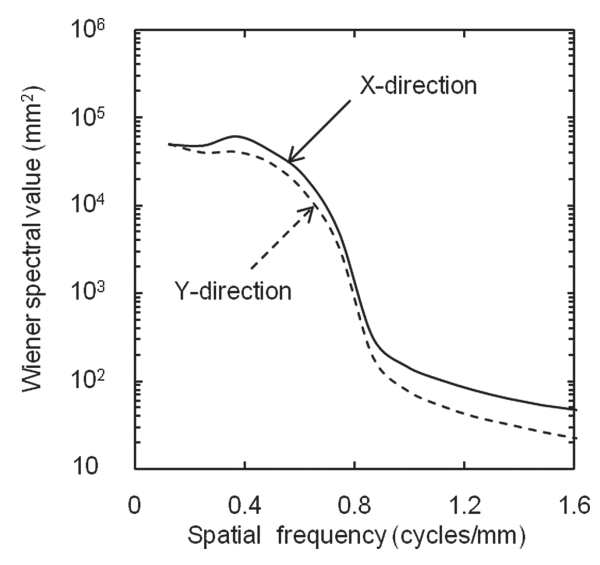

Fig. 5 Comparison of Wiener spectra (WS) measured at the center area of the CBCT image between $\mathrm{WS}_{\mathrm{X}}$ and $\mathrm{WS}_{\mathrm{Y}}$ acquired with $1024 \times 1024$ and 617 images.

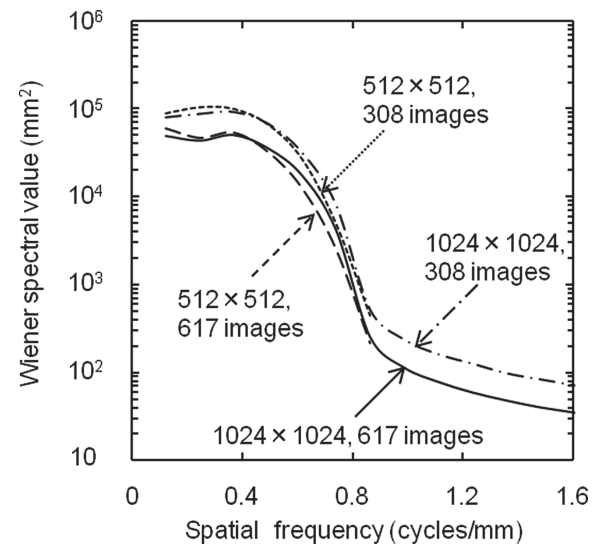

Fig. 6 Comparison of Wiener spectra (WS) measured at the center area of the CBCT image in the different acquisition parameters for scan matrix number of $1024 \times$ 1024 and $512 \times 512$ and projection number of 308 and 617 images. WS averaged of $\mathrm{WS}_{\mathrm{X}}$ and $\mathrm{WS}_{\mathrm{Y}}$ are reported.

mm の位置での WS を Fig. 10 に示す．ロール回転方 式におけるWS の值にZ 軸方向の位置による差はみ られなかった。

\section{3. 考 察}

$\mathrm{CBCT}$ 撮影条件のうち，収集画像数と収集マトリク スを 2 種類ずつ用いて解像特性とノイズ特性の評価を 行った。その結果，収集マトリクスが $512 \times 512$ の場合 に解像特性が劣っていた。 CT 画像の MTF は, 検出 器のアパーチャサイズやX 線管の焦点サイズによる 不鋭，再構成関数の周波数応答の影響を受ける ${ }^{10)}$. 今 回, X 線管の焦点サイズと再構成関数は同一の条件で 評価したため, 測定した MTF は CT 装置の検出器ア パーチャサイズに相当する FPD の検出素子面積によ り変化する。 $512 \times 512$ 収集 (60 frame/s)では, 1024×

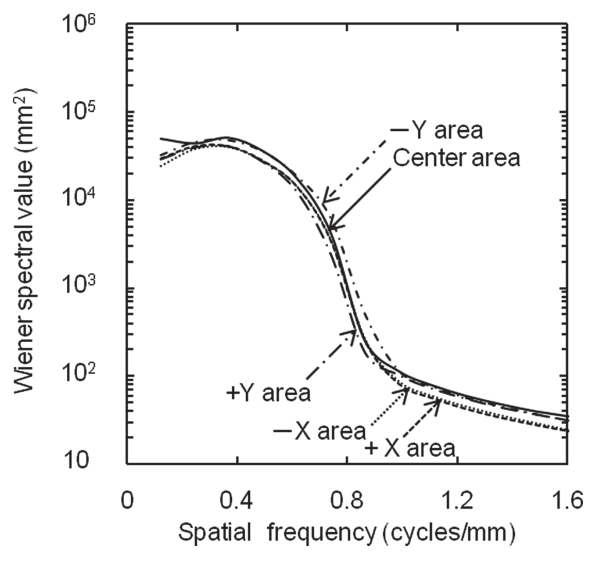

Fig. 7 Comparison of Wiener spectra (WS) measured at the center and the peripheral areas in X-Y plane of the CBCT image. WS averaged of $\mathrm{WS}_{\mathrm{X}}$ and $\mathrm{WS}_{\mathrm{Y}}$ acquired with $1024 \times 1024$ and 617 images are reported.

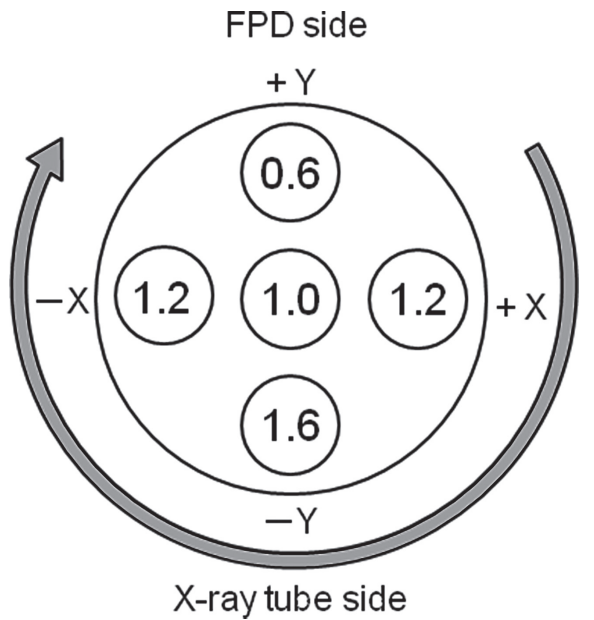

Fig. 8 Comparison of relative absorbed dose measured at the center and the peripheral areas in X-Y plane of the CBCT obtained with $1024 \times 1024$ and 617 images.

1024 収集 (30 frame/s) における $2 \times 2$ 画素を 1 画素と して画像収集する (binning 処理)ことから, デー夕収 集時の実効的な検出素子面積は $1024 \times 1024$ 収集時と 比べて広がるため, 周波数応答が変化し, 解像特性が 低下したと考えられる。収集画像数が減少すると, 解 像特性の高い 1024×1024 収集において回転中心から 離れた辺縁部で MTF の低下がみられた (Fig. 2b)。診 断用の CT 装置において, 回転中心から離れるにした

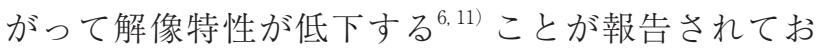
り, 本研究の結果は CT 装置と同様の特性と考える。 また, X-Y 面内の位置で解像特性が変化し, $\mathrm{MTF}_{\mathrm{X}}$ と $\mathrm{MTF}_{\mathrm{Y}}$ ともに $(0,-90,0)$ の位置で高く $(0,+90,0)$ の位 置で低い值を示した(Fig. 4)。この MTF に差があら われた 投影データのうち, 対向するデータが得られず 1 方向 

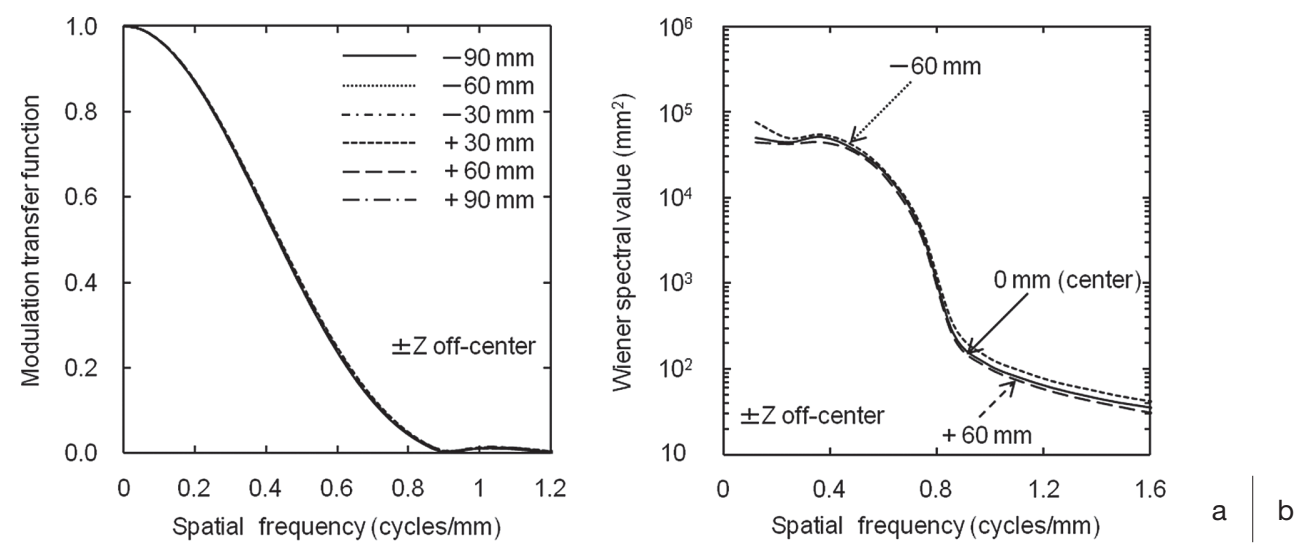

Fig. 9 (a) Comparison of $\mathrm{MTF}_{\mathrm{Y} S}$ measured at the position from various distance from the isocenter on the Z-axis acquired with $1024 \times 1024$ and 617 images.

(b) Comparison of Wiener spectra (WS) measured at the center of the CBCT image between the isocenter and $\pm 60 \mathrm{~mm}$ off-center on the Z-axis. WS averaged of $\mathrm{WS}_{\mathrm{X}}$ and $\mathrm{WS}_{\mathrm{Y}}$ acquired with $30 \mathrm{f} / \mathrm{s}-20 \mathrm{~s}$ are reported.

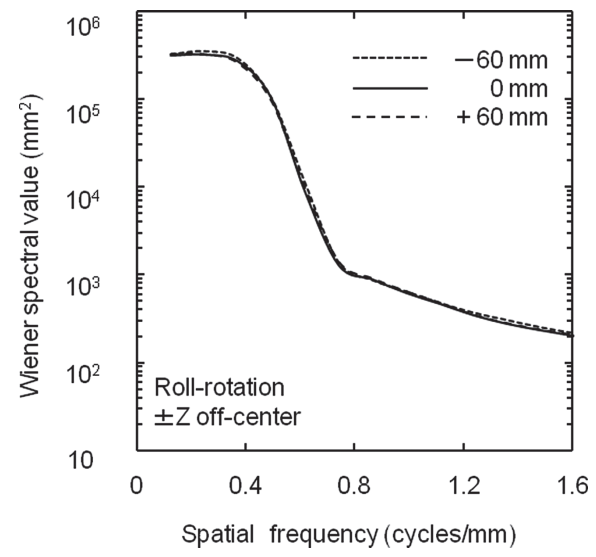

Fig. 10 Comparison of Wiener spectra (WS) measured at the center of the CBCT image using roll-rotation between the isocenter and $\pm 60 \mathrm{~mm}$ off-center on the Z-axis. WS averaged of $\mathrm{WS}_{\mathrm{X}}$ and $\mathrm{WS}_{\mathrm{Y}}$ are reported.

からのみ投影デー夕を得る方向である。-Y方向は辺 縁ほどX 線管に近いため像の拡大率が大きく，検出 器側である+Y方向では逆に拡大率が小さくなる。拡 大率が上昇すると焦点サイズの幾何学的不鋭による半 影の影響が大きくなる一方，投影像の周波数特性は高 周波側へスライドするため解像特性は向上する ${ }^{12.13)}$. したがって, 焦点サイズの半影による解像特性の悪化 に比べて拡大効果による解像特性の向上の割合が大き いために，-Y方向における解像特性が優れていたと 考える. 特に, 水平 (X 軸) 方向の投影デー夕は対方向 のデータが得られないため, $\mathrm{MTF}_{\mathrm{x}}$ で顕著に差があら われたと考える。この対方向データが得られない領域 に扔ける解像特性の違いについて，本研究とは異なる 血管撮影装置 (Artis zee TA，株式会社シーメンス・ ジャパン)を使用して検証実験を行った。Artis zee TA は, 本研究の血管撮影装置 (Allura Xper FD20)と 同じヨウ化セシウムをシンチレータに用いた間接変換 型FPD を搭載しており，200 度収集した投影データ
を feldkamp FBP 法によって CBCT の画像再構成を 行う. Table 2 に示寸画像収集条件を用いて，X線管 回転軌道上の $X$ 線管側 $(0,-90,0)$ と検出器側 $(0,+90,0)$ の位置での MTF を測定した結果, $\mathrm{MTF}_{\mathrm{X}}$ と $\mathrm{MTF}_{\mathrm{Y}}$ と もに $(0,-90,0)$ の位置で高く $(0,+90,0)$ の位置で低い 值を示し, 本研究の結果と同じ傾向がみられた (Fig. 11).したがって, 対方向のデータが得られない $\pm Y$ 領 域に抢ける解像特性の差は, 今回使用した装置固有の 特性ではなく, CBCT のデータ収集領域 (partial-scan) と幾何学的配置 (X 線管-検出器とスライス面内位置) による拡大効果が影響している可能性が高い.FBP 法により再構成した画像において，位置補正係数によ りスライス面内の解像特性が不均一であることが報告 されており ${ }^{14 \sim 16)}$, partial-scanによる画像再構成 ${ }^{17)}$ で の対方向データは実データではないため, 幾何学的配 置による影響が大きくあらわれたと考える。

画像の中心領域のノイズ特性は, 収集画像数が 2 倍 になると, WS がゼロ周波数付近から低下し，そのま 

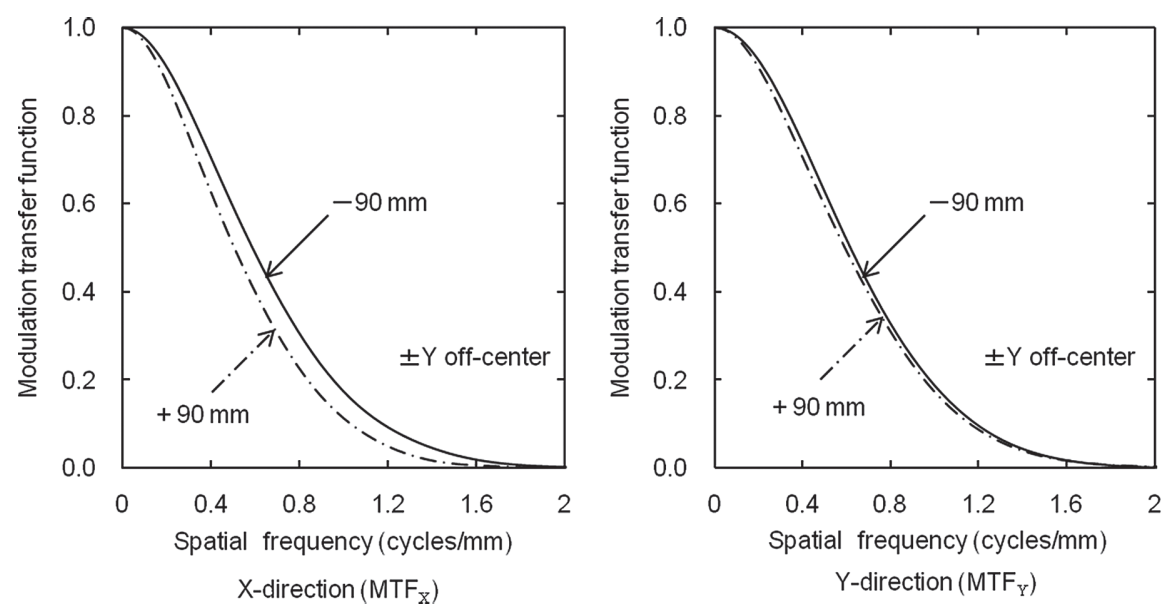

$a \mid b$

Fig. 11 Comparisons of $\mathrm{MTF}_{X S}$ (a) and $\mathrm{MTF}_{\mathrm{YS}}$ (b) measured at the $90 \mathrm{~mm}$ distance positions from the isocenter on the Y-axis acquired of different angiography system (Artis zee TA, SIEMENS Japan Co., Ltd.) used in this study.
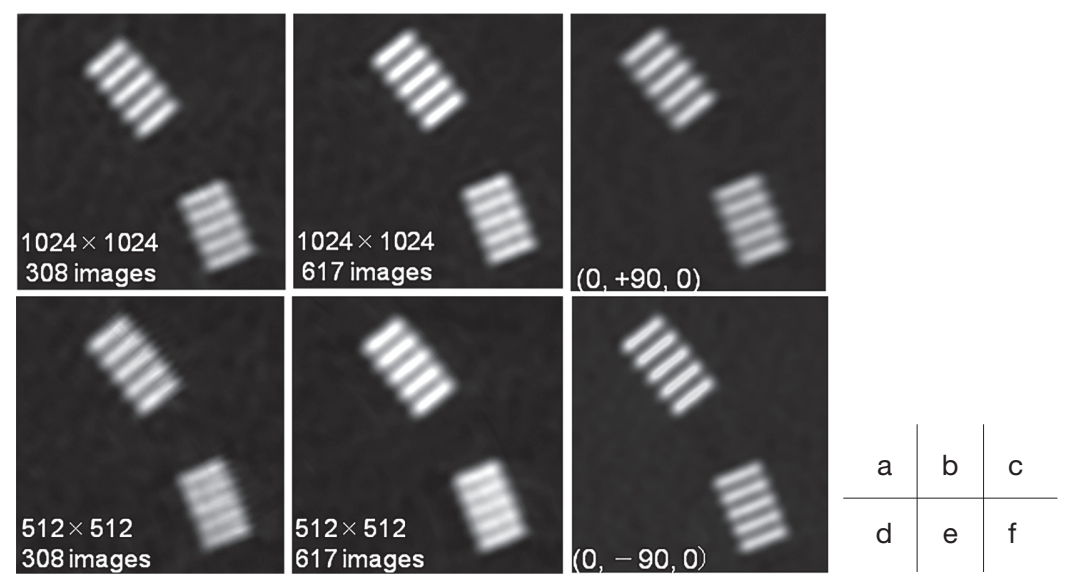

Fig. 12 Comparisons of close-up CBCT images for square wave chart phantom obtained by different acquisition parameters at the isocenter with (a) $1024 \times 1024 \& 308$ images, (b) $1024 \times 1024 \& 617$ images, (d) $512 \times 512 \& 308$ images, (e) $512 \times 512 \& 617$ images, and at (c) $+90 \mathrm{~mm}$, (f) $-90 \mathrm{~mm}$ off-center on the $\mathrm{Y}$-axis with $1024 \times 1024 \&$ 617 images. The same image reconstruction function and processing were employed for all images.

まの形状で下方に移動していた (Fig. 6)。また, 各撮 影条件で WS $\mathrm{W}_{\mathrm{X}}$ と比べて $\mathrm{WS}_{\mathrm{Y}}$ が低く，ゼロ周波数付近 に拈いてほぼ同じ值を示していた(Fig. 5)。撮影線量 を増加させると, WS はすべての空間周波数で平行に 低下する ${ }^{18)}$ ．しかし，軟部組織用の再構成関数やロー パスフィルタ処理により画像の解像特性を低下させる とゼロ周波数付近の值は変化しない ${ }^{18)}$. したがって, 収集画像数の増加によるWS の低下は投影デー夕の $\mathrm{X}$ 線光子数の増加が要因であり, $\mathrm{X}$ 軸方向と $\mathrm{Y}$ 軸方 向のノイズ特性の差は対方向デー夕の有無による周波 数特性の違いが影響したと考える。一方, 収集マトリ クス(画像収集レート)の違いによってノイズ特性に大 きな差がみられなかった. $512 \times 512$ 収集 (60 frame/s)
では $2 \times 2$ 画素を 1 画素としてデー夕収集するために 実効的な検出器素子面積が大きく, ノイズ特性は向上 する。しかし, 撮影線量は $33 \%$ 少ないためにX 線量 子ノイズは増加することから, これらの効果が互いに 打ち消しあいノイズ特性に差が出なかったと考える。

血管撮影システムに打ける CBCT のデー夕収集角 度は，360 度でないため X-Y 面内で均一な線量分布で なく ${ }^{19)}$, 本研究で使用した装置も先行研究と同様に回 転軌道上の $\mathrm{X}$ 線管側である-Y 領域で最も線量が多 く, 反対の検出器側である+Y 領域では最も少なかっ た (Fig. 8). 投影デー夕の X 線光子数が多いとノイズ 特性は向上するが，X-Y 面内の線量分布に対する各領 域の画像ノイズの分布は一致していなかった。この理 


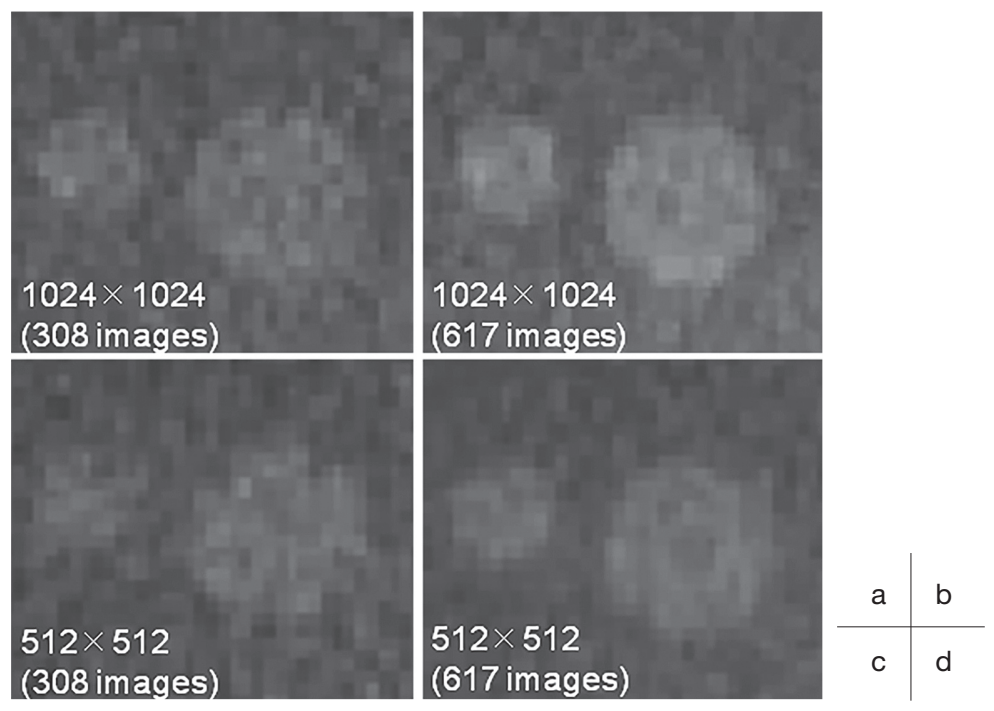

Fig. 13 Comparisons of close-up CBCT images for lowcontrast signal obtained by different acquisition parameters at the isocenter with (a) $1024 \times 1024 \& 308$ images, (b) $1024 \times 1024 \& 617$ images, (c) $512 \times 512 \&$ 308 images, (d) $512 \times 512 \& 617$ images. The same image reconstruction function and processing were employed for all images.

由は, 対方向デー夕が得られず線量差が大きい土Y 領 域は, partial-scan 再構成によってX 軸を対称に-Y 領 域の投影デー夕を折り返すことで+Y 領域のデータ補 間を行っているため, 線量分布のノイズ特性への影響 が小さかったためと考える。 また，X-Y 面内の各領域 でWS に差がみられ，空間周波数が 1.0 cycles $/ \mathrm{mm}$ 付 近でWS は交差していた(Fig. 7)。この要因として, partial-scan 再構成による画像再構成法と X-Y 面内各 領域の解像特性の双方が影響していると推察する。対 方向データが得られている $\mathrm{X}$ 方向の領域は, partialscan 再構成の投影データ折り返し補間によってデー 夕内の $\mathrm{X}$ 線光子数が計算上約 2 倍増加し, $\pm \mathrm{Y}$ 領域と 比べてノイズ特性に優れると予測する。しかし，ノイ ズ特性は解像特性の影響も受ける。 $\pm \mathrm{Y}$ 領域辺縁の MTF で顕著に差があらわれた 1.0 cycles $/ \mathrm{mm}$ までの 周波数带に㧈ける各領域の WS は, 画像中心㧍よび士 $\mathrm{X}$ 領域と比べて $+\mathrm{Y}$ 領域で低く, $-\mathrm{Y}$ 領域で高い值を示 し，解像特性の差による影響がみられた。MTFが 0 に収束した $1.0 \mathrm{cycles} / \mathrm{mm}$ 以降は, 解像特性の影響を 受けず partial-scan 再構成の投影デー夕折り返し補間 の影響によって, $\pm \mathrm{X}$ 領域の WS は, $\pm \mathrm{Y}$ および画像中 心領域より低い值を示したと考える。

コーン角中心から外れたスライス位置 $( \pm Z$ 方向 $)$ で は, 解像特性は中心領域と同等の MTF が得られたが WS に差がみられた (Fig. 9)。これまでにコーン角の 大きい CBCTの画質改良を目的とした画像再構成法
に関する研究は多く報告されており ${ }^{20 ~ 22)}$ ，本研究で使 用した装置において評価領域内でのコーン角の影響は 小さかったと考える. 本研究で使用したプロペラ回転 方式に㧍けるZ 軸方向は X 線管の陰極-陽極方向に該 当し(Fig. 1a)，陽極側 ( $-Z$ 方向)ではヒール効果によ り相対的にX 線質が硬く，X 線量は少ない，Liuら は，本研究と同じヨウ化セシウムをシンチレータに用 いた間接変換型 FPD の解像特性とノイズ特性につい て, 線質の硬化により解像特性の変化はみられずノイ ズ特性が劣化したとしている23. 効果による影響が $\pm Z$ 方向のノイズ特性にあらわれ， 陽極側である-Z方向のスライスで WS は高い值を示 したと考えられる。ロール回転におけるノイズ特性 は，Z 軸方向の位置による影響がみられないことから も, プロペラ回転に抢ける-Z方向のノイズの増加は, ヒール効果による影響が要因であることを示している.

CT 画像評価用の矩形波チャートファントムを, 4 種類の画像収集条件 (Table 1) と $\pm \mathrm{Y}$ 方向 $90 \mathrm{~mm}$ の位 置で撮影した画像を Fig. 12 に示す。また，低コント ラスト物質を 4 種類の画像収集条件 (Table 1) を用い て撮影した画像を Fig. 13 に示す。1024×1024 収集 (Fig. 12a, b) と-Y 方向 $90 \mathrm{~mm}$ の位置 (Fig. 12f)で撮影 した画像の解像特性の優位性と, 収集画像数が多い撮 影条件 (617 images, Fig. 13b, d)により得た画像のノイ ズ特性の優位性について，測定したMTF およびWS との整合性が画像から確認できる。頭部や腹部の 
CBCT T゙は, 被写体の体厚により目的部位が必ずしも 回転中心に位置しないため, 高い解像特性が求められ る頭蓋内ステントの描出や, 低コントラストな信号を 含みノイズの影響を受けやすい腹部血管造影などの撮 影に打いて, 回転中心からの位置や収集画像数の減少 により必要とされる画質を確保できない可能性があ る。そのため, CBCT のデータ収集条件によってX-Y 面内抄よびスライス位置における画像特性が異なるこ とを十分認識しておくことが必要である。

\section{4. 結 論}

本研究では, FPD を用いた血管撮影装置による $\mathrm{CBCT}$ 画像の画質 (解像特性とノイズ特性) を測定し, 収集画像数, 収集マトリクス, 回転中心からの位置が 及ぼす影響を調べた。その結果, 収集マトリクス 1024 ×1024を用いた解像特性が高い撮影条件において, 収
集画像数の減少により回転中心から離れた位置で MTF が低下した。 また，対方向データが得られない 領域に扮いて, 回転軌道上の X 線管側に近いほど高 い解像特性を示し, 検出器側に向かうほど低下した。 ノイズ特性は, 収集画像数の増加により改善し, X-Y 面内の位置およびX 線管の陰極-陽極方向で異なる画 像ノイズを示した.

\section{謝 辞}

本研究をまとめるにあたり，有益な御意見を頂いた 株式会社フィリップスエレクトロニクスジャパン村重 勝範氏に心より御礼申し上げます。

本研究の内容の一部は, 第 43 回日本放射線技術学 会秋季学術大会 (2015 年, 金沢)において発表した.

\section{参考文献}

1) Feldkamp LA, Davis LC, Kress JW, et al. Practical cone-beam algorithm. J Opt Soc Am A 1984; 1(6): 612-619.

2) 坂本 清, 三浦行矣, 植田 健, 他. FPD 搭載型コーン ビーム CT における低コントラスト分解能の評価. 日放 技学誌 2006; 62(4): 539-545.

3) Patel NV, Gounis MJ, Wakhloo AK, et al. Contrast-enhanced angiographic cone-beam CT of cerebrovascular stents: experimental optimization and clinical application. AJNR Am J Neuroradiol 2011; 32(1): 137-144.

4) Snoeren RM, Söderman M, Kroon JN, et al. High-resolution 3D $\mathrm{X}$-ray imaging of intracranial nitinol stents. Neuroradiology 2012; 54(2): 155-162.

5) Hounsfield GN. Computerized transverse axial scanning (tomography). 1. Description of system. Br J Radiol 1973; 46 (552): 1016-1022.

6) Hara T, Ichikawa K, Sanada S, et al. Image quality dependence on in-plane positions and directions for MDCT images. Eur J Radiol 2010; 75(1): 114-121.

7）遠藤真広, 飯沼 武, 竹中栄一. ワイヤによる CT 像の分 解能の測定. 日本医放会誌 1980; 40(1): 43-51.

8) Kijewski MF, Judy PF. The noise power spectrum of CT images. Phys Med Biol 1987; 32(5): 565-575.

9) Tward DJ, Siewerdsen JH. Noise aliasing and the $3 \mathrm{D}$ NEQ of flat-panel cone-beam $\mathrm{CT}$ : effect of $2 \mathrm{D} / 3 \mathrm{D}$ apertures and sampling. Med Phys 2009; 36(8): 3830-3843.

10) Mori I, Machida Y. Deriving the modulation transfer function of CT from extremely noisy edge profiles. Rad Phys \& Tech 2009; 2(1): 22-32.

11）原 孝則, 市川勝弘, 丹羽伸次. CT 撮像系におけるスラ イス面の位置と方向に対する解像力特性の評価. 日放技 学誌 2008; 64(1): 50-56.

12) Siewerdsen JH, Jaffray DA. Optimization of x-ray imaging geometry (with specific application to flat-panel cone-beam computed tomography). Med Phys 2000; 27(8): 1903-1914.

13) Boyce SJ, Samei E. Imaging properties of digital magnification radiography. Med Phys 2006; 33(4): 984-996.

14) Zeng GL. Nonuniform noise propagation by using the ramp filter in fan-beam computed tomography. IEEE Trans Med Imag 2004; 23(6): 690-695.

15) Pan $\mathrm{X}, \mathrm{Yu} \mathrm{L}$. Image reconstruction with shift-variant filtration and its implication for noise and resolution properties in fanbeam computed tomography. Med Phys 2003; 30(4): 590-600.

16) Wang J, Lu H, Li T, et al. An alternative solution to the nonuniform noise propagation problem in fan-beam FBP image reconstruction. Med Phys 2005; 32(11): 3389-3394.

17) Parker DL. Optimal short scan convolution reconstruction for fan beam CT. Med Phys 1982; 9(2): 254-257.

18）西丸英治, 市川勝弘, 原 孝則, 他. 逐次近似法を応用し たCT 画像の新しい Noise Power Spectrum 測定法の検討. 日放技学誌 2012; 68(12): 1637-1643.

19）高瀬 正, 木内克典, 武 俊夫, 他. 血管造影撮影装置搭 載コーンビーム CT の特徵. 日放技学誌 2009; 65(6): 755764.

20) Grass M, Köhler T, Proksa R. 3D cone-beam CT reconstruction for circular trajectories. Phys Med Biol 1999; 45(2): 329-347.

21) Mori S, Endo M, Komatsu $S$, et al. A combination-weighted Feldkamp-based reconstruction algorithm for cone-beam CT. Phys Med Biol 2006; 51(16): 3953-3965.

22) Ning $R$, Tang $X$, Conover $D$. X-ray scatter correction algorithm for cone beam CT imaging. Med Phys 2004; 31(5): 1195-1202.

23) Liu $X$, Shaw CC. A-Si: H/CsI(Tl) flat-panel versus computed radiography for chest imaging applications: image quality metrics measurement. Med Phys 2004; 31(1): 98-110. 